\title{
The effectiveness of jute and coir blankets for erosion control in different field and laboratory conditions
}

\author{
Jana Kalibová ${ }^{1}$, Lukáš Jačka ${ }^{2}$, and Jan Petrü ${ }^{1}$ \\ ${ }^{1}$ Department of Land Use and Improvement, Faculty of Environmental Sciences, Czech University of Life \\ Sciences Prague, Prague, Kamýcká 129, Praha 6 - Suchdol, 165 21, Czech Republic \\ ${ }^{2}$ Department of Water Resources and Environmental Modelling, Faculty of Environmental Sciences, \\ Czech University of Life Sciences Prague, Prague, Kamýcká 129, Praha 6 - Suchdol, 165 21, Czech Republic \\ Correspondence to: Jana Kalibová (kalibova@ fzp.czu.cz)
}

Received: 12 January 2016 - Published in Solid Earth Discuss.: 18 January 2016

Revised: 9 March 2016 - Accepted: 10 March 2016 - Published: 30 March 2016

\begin{abstract}
Vegetation cover is found to be an ideal solution to most problems of erosion on steep slopes. Biodegradable geotextiles (GTXs) have been proved to provide sufficient protection against soil loss in the period before vegetation reaches maturity, so favouring soil formation processes. In this study, $500 \mathrm{~g} \mathrm{~m}^{-2}$ jute (J500), $400 \mathrm{~g} \mathrm{~m}^{-2}$ (C400), and $700 \mathrm{~g} \mathrm{~m}^{-2}$ coir (C700) GTXs were first installed on a $9^{\circ}$ slope under "no-infiltration" laboratory conditions, then on a $27^{\circ}$ slope under natural field conditions. The impact of GTXs on run-off and soil loss was investigated to compare the performance of GTXs under different conditions. Laboratory run-off ratio (percentage portion of control plot) equalled 78, 83 , and $91 \%$, while peak discharge ratio equalled 83,91 , and $97 \%$ for J500, C700, and C400 respectively. In the field, a run-off ratio of 31,62 , and $79 \%$, and peak discharge ratio of 37,74 , and $87 \%$ were recorded for C700, J500, and C400 respectively. All tested GTXs significantly decreased soil erosion. The greatest soil loss reduction in the field was observed for J500 (by 99.4\%), followed by C700 (by 97.9\%) and C400 (by $93.8 \%$ ). Irrespective of slope gradient or experimental condition, C400 performed with lower run-off and peak discharge reduction than J500 and C700. The performance ranking of J500 and C700 in the laboratory differed from the field, which may be explained by different slope gradients, and also by the role of soil, which was not included in the laboratory experiment.
\end{abstract}

\section{Introduction}

Land degradation causes high erosion rates as a consequence of agriculture, grazing, mining, forest fires or deforestation and this causes economic, social and environmental damage (Cerdà, 1998; Cerdà et al., 2010; Erkossa et al., 2015; Keesstra et al., 2014; Lieskovský and Kenderessy, 2014; Moreno-Ramón et al., 2014; Stanchi et al., 2015). However, the largest erosion rates and the most degraded soils are usually found in areas affected by development, infrastructure or urbanization (Cerdà, 2007; Pereira et al., 2015; Sadeghi et al., 2015; Seutloali and Beckedahl, 2015; Yuan et al., 2015).

Civil engineering projects often result in steep slopes with bare soil, which is highly vulnerable to soil erosion, caused by either impact energy from raindrops or by surface run-off (Weggel and Rustom, 1992). Well-established, low-growing, dense vegetation cover is able to control soil loss by 2 or 3 orders of magnitude compared to bare soil conditions (Keesstra et al., 2016; Ola et al., 2015; Rickson, 2006). The highest reduction of erosive run-off was recorded on permanently grassed plots (Álvarez-Mozos et al., 2014). However, the establishment of vegetation cover can be disrupted during early plant growth stages, leaving the slopes exposed to further erosion processes with negative consequences for slope stability (Rickson, 1988). Soils play a pivotal role in major global biogeochemical cycles (carbon, nutrients, and water), while hosting the largest diversity of organisms on land. Because of this, soils deliver fundamental ecosystem services, and management to change a soil process in support of one ecosystem service can either provide co-benefits to other ser- 
vices or it can result in trade-offs. Therefore, the necessity of protecting the soil is non-negligible (Berendse et al., 2015; Brevik et al., 2015; Decock et al., 2015; Keesstra et al., 2012; Smith et al., 2015). This is why there is a trend in the research to protect soil with mulches, amendments, and other erosion control measures (Álvarez-Mozos et al., 2014; Hu et al., 2015; Hueso-Gonzáles et al., 2014; Keesstra et al., 2016; Prosdocimi et al., 2016; Yazdanpanah et al., 2016).

Biological/biodegradable geotextiles (GTXs), made out of jute, coir, rice, straw etc., have often been proved to be effective, sustainable, and eco-friendly alternatives to synthetic erosion control materials used for preventing soil erosion and subsequent slope degradation processes in the period before vegetation reaches maturity, thus facilitating pedogenic processes (Fullen et al., 2007; Jordán et al., 2011; Khan and Binoy, 2012; Langford and Coleman, 1996; Morgan and Rickson, 1995; Ogbobe et al., 1998; Sutherland and Ziegler, 2007; etc.). The range of GTXs is wide. The choice of an individual product may be most convenient when based on the ratio of GTX cost to effectiveness.

Many case studies evaluating the effect of jute and coir GTXs on slopes have been carried out across the world, but the reported effectiveness of GTXs varies (Giménez-Morera et al., 2010; see Table 1). Therefore, the results cannot be generalized (Cantón et al., 2011; Rickson, 2005). Furthermore, because of various site conditions, it is difficult to determine the extent to which soil loss reduction was caused by GTXs and not by other factors, e.g. vegetation cover (Fifield, 1992; Toy and Hardley, 1987).

This paper presents a study in which the effectiveness of three jute and coir fibre rolled erosion control systems (see Table 2), which are commercially available and widely applied worldwide, were tested under both laboratory and field conditions. No product with dense coverage (non-woven) was included, as these are not as effective in reducing run-off (Luo et al., 2013) and can produce even more run-off than bare soil (Davies et al., 2006; Mitchell et al., 2003).

Unlike previous laboratory studies, the impact of GTXs was examined on "no-soil" subgrade to omit one of the most variable factors affecting soil erosion - soil itself (Smets et al., 2011) - and to assess the effectiveness based on nothing but GTX properties. Due to the infiltration process, soil supports the erosion control effect of GTXs, providing less water for overland flow (Beven, 2011). Assuming that soil affects all GTXs equally in the field, the laboratory records of surface run-off volume (L) and peak discharge $\left(\mathrm{L} \mathrm{s}^{-1}\right)$ reduction should proportionally match the data from field experiments. Concerning the shear stress of overland flow, the character of surface run-off volume and velocity reduction in the laboratory should reflect soil loss reduction in the field as well (Harmon and Doe, 2001; Morgan and Rickson, 1995; Thompson, 2001).

The objective of this experiment was to test the impact of biodegradable erosion control GTXs on surface run-off on a slope exposed to simulated rainfall under laboratory and field

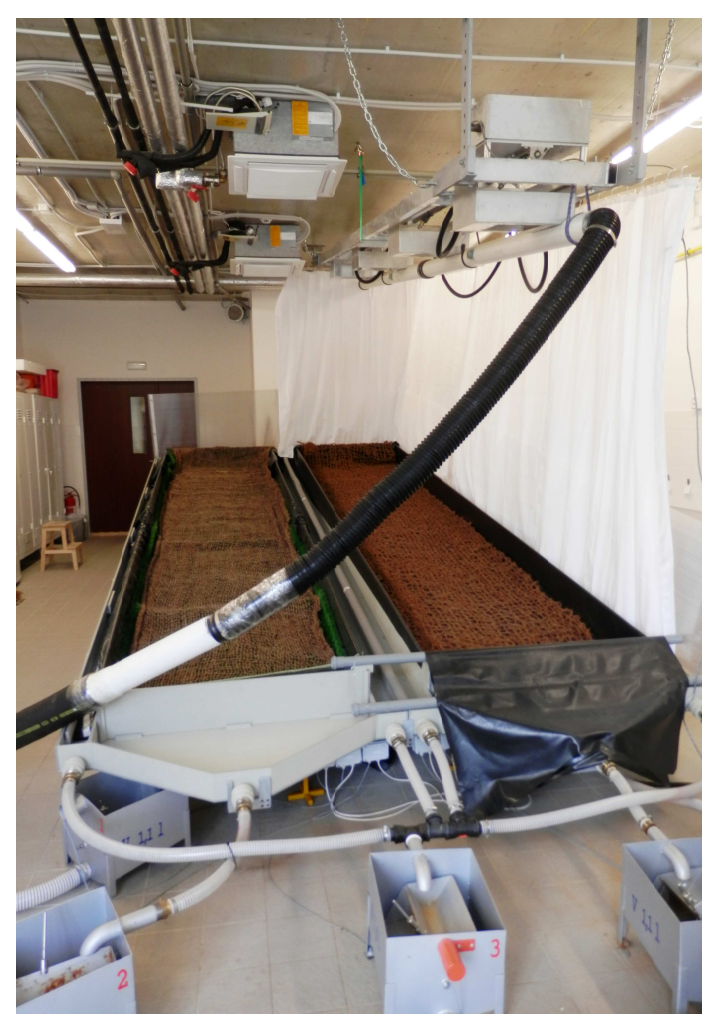

Figure 1. A Norton Ladder Rainfall Simulator is positioned above test beds with mechanical toggle flow meters. A C400 erosion control net is spread over the test bed.

conditions, to rank the effectiveness of GTXs in run-off reduction, and to compare the run-off data trends under laboratory conditions (where soil subgrade and infiltration process were excluded) with data trends under different field conditions (including soil subgrade and different slope gradients).

\section{Materials and methods}

\subsection{Laboratory experiment}

Laboratory experiments were conducted in the rainfall simulation laboratory at the Czech University of Life Sciences Prague, using a Norton Ladder Rainfall Simulator. Rainfall simulations have been used since the 1930s by scientists to study soil erosion by water and soil hydrology. They are one of the most used and most successful tools used in disciplines such as agronomy, hydrology, and geomorphology (Cerdà, 1998; Martínez-Murillo et al., 2013; Rodrigo Comino et al., 2015, 2016; Iserloh et al., 2013a, b). In this study, the rainfall simulator uses four Veejet 80100 nozzles, with a water pressure of $0.04 \mathrm{MPa}$, height of $1.9 \mathrm{~m}$ and target area of $4.9 \mathrm{~m} \times 1.05 \mathrm{~m}$. The main rainfall characteristics are as follows: mean rainfall intensity $I=105 \mathrm{~mm} \mathrm{~h}^{-1}$, timespecific kinetic energy $\mathrm{KE}_{\mathrm{R}}=1269 \mathrm{~J} \mathrm{~m}^{-2} \mathrm{~h}^{-1}$, volumespecific kinetic energy $\mathrm{KE}=12 \mathrm{~J} \mathrm{~m}^{-2} \mathrm{~mm}^{-1}$, median vol- 
Table 1. Overview of studies investigating the impact of J500 (jute) $\left(500 \mathrm{~g} \mathrm{~m}^{-2}\right)$ and C400, C700 (coir) $\left(400 ; 700 \mathrm{~g} \mathrm{~m}^{-2}\right)$ GTXs on surface run-off and soil erosion by water since $2000^{1}$.

\begin{tabular}{|c|c|c|c|c|c|c|c|c|}
\hline Author & $\begin{array}{l}\text { GTX } \\
\text { type }\end{array}$ & $\begin{array}{l}\text { Soil type } \\
\text { (sand-silt-clay; \%) }\end{array}$ & $\begin{array}{r}\text { Slope } \\
{\left[{ }^{\circ}\right]}\end{array}$ & $\begin{array}{l}\text { Simulated rainfall } \\
\text { intensity } \\
{\left[\mathrm{mm} \mathrm{h}^{-1}\right]}\end{array}$ & $\begin{array}{l}\text { Control sample } \\
\text { cover type }\end{array}$ & $\begin{array}{l}\text { Run-off } \\
\text { reduction } \\
\text { [\% of control] }\end{array}$ & $\begin{array}{l}\text { Soil loss } \\
\text { [\% of control] }\end{array}$ & $\begin{array}{l}\text { Lab./ } \\
\text { field } \\
{[\mathrm{L} / \mathrm{F}]}\end{array}$ \\
\hline \multirow[t]{2}{*}{ Álvarez-Mozos et al. (2014) } & $\mathrm{J} 500$ & silty clay loam (13.8-53.9-32.3) & $45^{\circ}$ & $\max .31 .2$ & hydroseeded soil & 266 & 31 & $\mathrm{~F}$ \\
\hline & J500 & silty clay loam (13.8-53.9-32.3) & $60^{\circ}$ & $\max .31 .3$ & hydroseeded soil & 238 & 40 & $\mathrm{~F}$ \\
\hline Shao et al. (2014) & $\mathrm{J} 500$ & mixed substrate & $40^{\circ}$ & 50 & bare substrate & 37.9 & 0.3 & $\mathrm{~L}$ \\
\hline Khan and Binoy (2012) & $\mathrm{J} 500$ & sandy & $33^{\circ}$ & 122 & bare soil & 83 & 10 & $\mathrm{~L}$ \\
\hline Jakab et al. (2012) & J500 & silty loam (23-70-7) & $8.5^{\circ}$ & $\max .38 .7$ & bare soil & $47,74,119$ & 20 & $\mathrm{~F}$ \\
\hline Kertész et al. (2007) & $\mathrm{J} 500$ & silty loam & $11^{\circ}$ & $\max .83$ & bare soil & $30-250$ & $7-306$ & $\mathrm{~F}$ \\
\hline \multirow[t]{2}{*}{ Sutherland and Ziegler (2007) } & $\mathrm{C} 700$ & clay (24-34-42) & $5.5^{\circ}$ & 35 & bare soil & 84 & 0.4 & $\mathrm{~F}$ \\
\hline & $\mathrm{C} 400$ & clay $(24-34-42)$ & $5.5^{\circ}$ & 35 & bare soil & 90 & 8 & $\mathrm{~F}$ \\
\hline \multirow[t]{2}{*}{ Rickson (2006) } & $\mathrm{J} 500$ & sandy loam & $10^{\circ}$ & 72 & bare soil & 102 & 15 & $\mathrm{~L}$ \\
\hline & $\mathrm{C} 700$ & sandy loam & $10^{\circ}$ & 72 & bare soil & 106 & 51 & $\mathrm{~L}$ \\
\hline Sutherland and Ziegler (2006) & $\mathrm{J} 500, \mathrm{C} 700$ & clay-dominated oxisol & $5.5^{\circ}$ & 35,114 & bare soil & $91-104$ & 17 & $\mathrm{~F}$ \\
\hline Lekha (2004) & $\mathrm{C} 700$ & sandy loam & $26^{\circ}$ & $\mathrm{NA}^{2}$ & seeded bare soil & $\mathrm{NA}^{2}$ & $0.4-21.9$ & $\mathrm{~F}$ \\
\hline Mitchel et al. (2003) & $\mathrm{J} 500$ & loamy sand & $15^{\circ}$ & $\mathrm{NA}^{2}$ & bare soil & 35 & 1 & $\mathrm{~F}$ \\
\hline \multirow[t]{4}{*}{ Rickson (2000) } & $\mathrm{J} 500$ & sandy loam & $10^{\circ}$ & 35 & bare soil & 90 & 14 & $\mathrm{~L}$ \\
\hline & $\mathrm{C} 700$ & sandy loam & $10^{\circ}$ & 35 & bare soil & 97 & 25 & $\mathrm{~L}$ \\
\hline & $\mathrm{J} 500$ & sandy loam (68.1-22.1-9.8) & $10^{\circ}$ & 95 & bare soil & 90 & 23 & $\mathrm{~L}$ \\
\hline & $\mathrm{C} 700$ & sandy loam (68.1-22.1-9.8) & $10^{\circ}$ & 95 & bare soil & 102 & 23 & $\mathrm{~L}$ \\
\hline
\end{tabular}

${ }^{1}$ For studies carried out before the year 2000, see papers by Bhattacharyya et al. (2010) or Ingold and Thompson (1986). ${ }^{2} \mathrm{NA}=$ not available.

Table 2. Main characteristics of three tested biological GTXs.

\begin{tabular}{|c|c|c|c|}
\hline Treatment & 1 - Jute net & $2-$ Coir net & $3-$ Coir net \\
\hline Marking & $\mathrm{J} 500$ & $\mathrm{C} 400$ & $\mathrm{C} 700$ \\
\hline Material & $100 \%$ jute fibre & $100 \%$ coir fibre & $100 \%$ coir fibre \\
\hline Description & $\begin{array}{l}\text { open weave biodegradable } \\
\text { jute geotextile } \\
\text { in a grid structure }\end{array}$ & $\begin{array}{l}\text { open weave biodegradable } \\
\text { coir geotextile } \\
\text { in a grid structure }\end{array}$ & $\begin{array}{l}\text { open weave biodegradable } \\
\text { jute geotextile } \\
\text { in a grid structure }\end{array}$ \\
\hline Mass per area $\left(\mathrm{g} \mathrm{m}^{-2}\right)$ & 500 & 400 & 700 \\
\hline Mesh size $(\mathrm{mm} \times \mathrm{mm})$ & $15 \times 15$ & $35 \times 35$ & $20 \times 20$ \\
\hline Thickness (mm) & 2 & 7 & 8 \\
\hline Open area $(\%)$ & 60 & 65 & 50 \\
\hline Working life (years) & $1-2$ & $3-4$ & $3-7$ \\
\hline Average price $\left(\mathrm{EUR} \mathrm{m}^{-2}\right)^{*}$ & $0.61-0.96$ & $0.89-1.29$ & $1.29-2.09$ \\
\hline
\end{tabular}

* Data obtained from several GTX suppliers.

umetric drop diameter $d_{50}=0.44 \mathrm{~mm}$, Christiansen uniformity $\mathrm{CU}=79 \%$. A slope gradient of $9^{\circ}$ was used for the experiment. An impermeable plastic film spread over the test bed was used as a control. The tested GTXs were then laid onto the plastic film to simulate no-infiltration conditions (see Fig. 1). All treatments were exposed to rainfall of $1.75 \mathrm{~mm} \mathrm{~min}^{-1}$ intensity and $15 \mathrm{~min}$ duration. Ten rainfall simulations were carried out on each treatment (control, J500, C400, C700). To provide constant starting conditions, a $15 \mathrm{~min}$ rainfall of $1.75 \mathrm{~mm} \mathrm{~min}^{-1}$ intensity was applied before each simulation. During a rainfall event, runoff initiation time $t_{i}$ [s] was recorded, run-off was collected by a mechanical toggle flow meter, and the time for each toggle was electronically recorded. Total run-off volume at time $=15 \min R_{15}[\mathrm{~L}]$ and peak discharge $Q\left[\mathrm{~L} \mathrm{~s}^{-1}\right]$ were measured. An outline of the laboratory experiments is given in Table 3.

\subsection{Field experiment}

The field simulations were carried out on the south slope of the Rokycany-Pilsen rail corridor near the village of Klabava $\left(49^{\circ} 44^{\prime} 56.938^{\prime \prime} \mathrm{N}, 13^{\circ} 32^{\prime} 17.887^{\prime \prime} \mathrm{E}\right)$ in the Pilsen Region, Czech Republic. According to Quitt's classification, Klabava falls into a moderately warm region with mean annual air temperature of $8^{\circ} \mathrm{C}$ and mean annual precipitation of $550 \mathrm{~mm}$ (Tolasz, 2007). The experimental slope was formed by a $1: 2\left(27^{\circ}\right)$ cut. The stabilized unmade ground was covered by a gravelly loam soil layer of $0.3 \mathrm{~m}$ thickness, $1.40 \mathrm{~g} \mathrm{~cm}^{-3}$ bulk density, and $47 \%$ porosity. A particle size analysis was performed using a hydrometer method (SISTTS CEN ISO/TS, 17892-4:2004, 2004). The soil texture was classified using the system of the United States Department of Agriculture. The tested soil was classified as gravelly loam ( $24 \%$ clay, $40 \%$ silt, $36 \%$ sand). The percentage of gravel 
Table 3. An outline of laboratory and field experiments testing the impact of biological GTXs on surface run-off and soil loss.

\begin{tabular}{lll}
\hline & $\begin{array}{l}\text { Laboratory } \\
\text { experiments }\end{array}$ & $\begin{array}{l}\text { Field } \\
\text { experiments }\end{array}$ \\
\hline Substrate type & $\begin{array}{l}\text { impermeable } \\
\text { plastic film }\end{array}$ & $\begin{array}{l}\text { gravelly } \\
\text { loam }\end{array}$ \\
Slope $\left(^{\circ}\right)$ & 9 & 27 \\
Rainfall intensity $\left(\mathrm{mm} \mathrm{h}^{-1}\right)$ & 105 & 80 \\
Experiment duration $(\mathrm{min})$ & 15 & 15 \\
Cover type & J500, C400, & J500, C400, \\
& C700 & C700 \\
Control cover & impermeable & bare gravelly \\
& plastic film & loam \\
Replications & 10 & 3 \\
Total number of experiments & 40 & 12 \\
\hline
\end{tabular}

(> $2 \mathrm{~mm}$ ) was $26 \%$. The estimated organic matter content of the soil was $3.5 \%$. The loss-on-ignition method (heated destruction of all organic matter) was used for the calculation of the organic matter content in the soil (ASTM, 2000; Schumacher, 2002; Nelson and Sommers, 1982).

Four rectangular plots (one control and three for the GTX treatments), each covering an area of $1.8 \mathrm{~m} \times 8.5 \mathrm{~m}$, were outlined by iron barriers on each side and a triangular collecting trough at the bottom (see Fig. 2). Afterwards erosion control nets were installed. A bare soil plot was used as a control.

The rainfall was simulated by four FullJet nozzles, with water pressure of $0.03 \mathrm{MPa}$ and height $2.4 \mathrm{~m}$ above the plots. Rainfall application did not differ significantly among treatments $(a=0.05)$. Three replications of each treatment were carried out at an overall mean intensity of $1.33 \pm 2 \mathrm{~mm} \mathrm{~min}^{-1}$ (a 10-year return period at the study site). To provide constant starting conditions, a $15 \mathrm{~min}$ rainfall of $1.33 \mathrm{~mm} \mathrm{~min}^{-1}$ intensity was applied before each simulation. For an outline of the field experiment see Table 3.

For operational reasons, it was necessary to spread the simulations over a period of two days. The measurements were therefore carried out under slightly different moisture conditions. The control treatment was measured on the first day with initial volumetric soil moisture content at $20.7 \%$. The GTX treatments were measured the following day with initial volumetric soil moisture content at $13.1 \%$ (an average value of nine records - three for each plot; the individual values did not differ significantly). The volumetric soil moisture content was determined using the gravimetric method (e.g. Kutílek and Nielsen, 1994) from undisturbed soil samples $\left(100 \mathrm{~cm}^{3}\right)$ that were collected in the top soil. During the rainfall event, run-off initiation time $t_{i}$ [s] was recorded, run-off was collected by a mechanical toggle flow meter with electronic recording of time for each toggle, and the total run-off volume $[\mathrm{L}]$ and discharge $\left[\mathrm{L} \mathrm{s}^{-1}\right]$ were measured. After the rainfall event, sediment concentration $\left[\mathrm{g} \mathrm{L}^{-1}\right]$ of the run-off

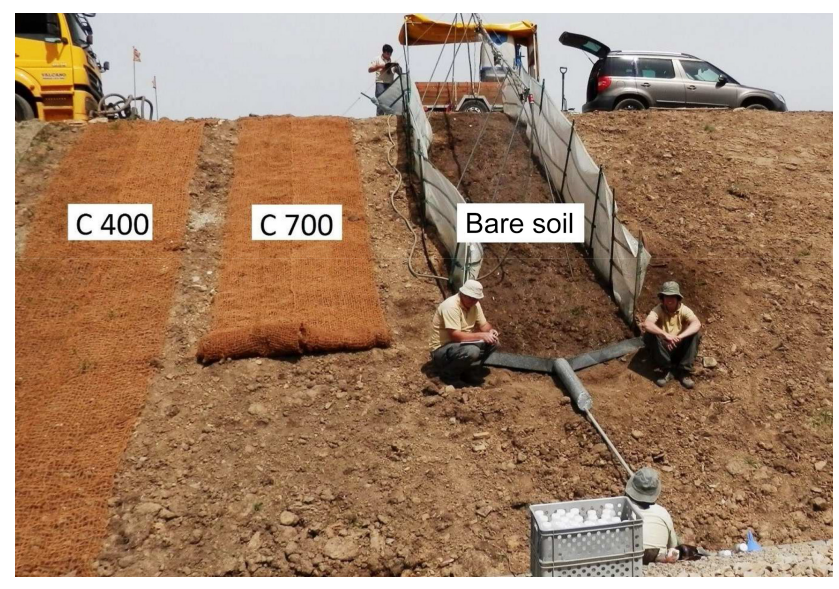

Figure 2. Experimental slope in the field (Rokycany, Czech Republic). Rainfall simulation on bare soil (control sample) in progress. Note: the iron collecting trough at the bottom of the plot is hidden below the eroded material, as the image was taken during the rainfall simulation.

was determined by oven-drying five collected run-off samples at $105^{\circ} \mathrm{C}$ for $48 \mathrm{~h}$, and subsequent weighing of the samples and sediment load (soil loss SL) [g] was calculated by multiplying the mean sediment concentration by total run-off volume.

\subsection{Data analysis}

All analyses were performed using Excel 2010 and R statistical software. One-way analysis of means was used to test whether the differences in laboratory values of time to runoff initiation $t_{i}$ [s], run-off at time $t=15 \mathrm{~min} R_{15}$ [L] and peak discharge $Q\left[\mathrm{~L} \mathrm{~s}^{-1}\right]$ are caused by sampling variation, at significance level 0.05 . A Welch two-sample $t$ test, not assuming equal variances, was used to compare mean values of $t_{i}, R_{15}$ and $Q$ for each treatment. The null hypothesis was defined as follows: the true difference in means is equal to zero.

In order to compare run-off (and soil loss) rates from field and laboratory plots, run-off ratios $\mathrm{RR}_{15}$ (Eq. 1), peak discharge ratios QR (Eq. 2), and soil loss ratios SLR (Eq. 3) were calculated and expressed as a portion of control [\%]:

$$
\begin{aligned}
\mathrm{RR}_{15} & =\frac{R_{15 \text { geotextile }}}{R_{15 \text { control }}} \times 100 \\
\mathrm{QR} & =\frac{Q_{\text {geotextile }}}{Q_{\text {control }}} \times 100 \\
\mathrm{SLR} & =\frac{\mathrm{SL}_{\text {geotextile }}}{\mathrm{SL}_{\text {control }}} \times 100 .
\end{aligned}
$$

Ratios were calculated from mean values of variables. 
Table 4. Statistical description of peak discharge for $500 \mathrm{~g} \mathrm{~m}^{-2}$ jute net (J500), $400 \mathrm{~g} \mathrm{~m}^{-2}$ coir net (C400), and $700 \mathrm{~g} \mathrm{~m}^{-2}$ coir net (C700) in laboratory experiments.

\begin{tabular}{llllll}
\hline Parameters & Units & Control & J500 & C400 & C700 \\
\hline Arithmetic mean & $\mathrm{L} \mathrm{s} \mathrm{s}^{-1}$ & 0.151 & 0.126 & 0.146 & 0.137 \\
Standard deviation & $\mathrm{L} \mathrm{s}^{-1}$ & 0.0005 & 0.0076 & 0.0025 & 0.0015 \\
Median & $\mathrm{L} \mathrm{s}^{-1}$ & 0.151 & 0.126 & 0.145 & 0.138 \\
Minimum & $\mathrm{L} \mathrm{s}^{-1}$ & 0.150 & 0.117 & 0.143 & 0.135 \\
Maximum & $\mathrm{L} \mathrm{s} \mathrm{s}^{-1}$ & 0.150 & 0.140 & 0.150 & 0.139 \\
Range & $\mathrm{L} \mathrm{s}^{-1}$ & 0.001 & 0.023 & 0.007 & 0.004 \\
Coefficient of variation & $\%$ & 0.004 & 0.058 & 0.017 & 0.011 \\
Cl mean 0.95* & $\mathrm{L} \mathrm{s}^{-1}$ & 0.0004 & 0.0056 & 0.0019 & 0.0011 \\
\hline * The confidence interval of the & $\mathrm{mean} \mathrm{calculated} \mathrm{at} \mathrm{the} 0.95^{*}$ & & &
\end{tabular}

\section{Results}

A statistical description of the results of peak discharge $Q$ $\left(\mathrm{L} \mathrm{s}^{-1}\right)$ is shown in Table 4. Run-off $R_{15}$ data were analysed analogically.

The mean time to run-off initiation of the simulated rainfall in the laboratory was $16.3 \mathrm{~s}$ (standard deviation $\sigma=0.46 \mathrm{~s})$ for control, $21.3 \mathrm{~s}(\sigma=0.46 \mathrm{~s})$ for $\mathrm{J} 500,21.1 \mathrm{~s}$ $(\sigma=1.30 \mathrm{~s})$ for $\mathrm{C} 400$ and $25.8 \mathrm{~s}(\sigma=1.54 \mathrm{~s})$ for $\mathrm{C} 700$. The results of a one-way analysis of mean values of runoff $t_{i}(\mathrm{~F}=28.484$, num $\mathrm{d} f=2.000$, denom $\mathrm{d} f=14.076$, $p$ value $=1.127 \times 10^{-5}$, equal variance of data sets are not assumed) indicate that the differences in mean values of measured GTX samples are not caused by sampling variation at significance level 0.05. The null hypothesis ("The true difference in means of time to run-off initiation is equal to zero") was rejected (by the Welch two-sample $t$ test, not assuming equal variances) for all comparisons except C700 vs. C400 at significance level 0.05 (see Table 6).

Mean run-off $R_{15}$ in the laboratory was $130.9 \mathrm{~L}$ $(\sigma=0.30 \mathrm{~L})$ for control, $102.2 \mathrm{~L}(\sigma=5.21 \mathrm{~L})$ for $\mathrm{J} 500$, $118.6 \mathrm{~L}(\sigma=1.43 \mathrm{~L})$ for $\mathrm{C} 400$ and $109.0 \mathrm{~L}(\sigma=1.79 \mathrm{~L})$ for C700. The results of a one-way analysis of mean values of run-off $R_{15}(\mathrm{~F}=100.414$, num d $f=2.000$, denom d $f=16$. $201, p$ value $=7.432 \times 10^{-10}$, equal variance of data sets are not assumed) indicate that the differences in mean values of measured GTX samples are not caused by sampling variation at significance level 0.05 . The null hypothesis ("The true difference in means of run-off is equal to zero") was rejected for all comparisons (see Table 6).

The results of a one-way analysis of mean values of peak discharge $Q(\mathrm{~F}=52.051$, num $\mathrm{d} f=2.000$, denom $\mathrm{d} f=13.494, p$ value $=4.53 \times 10^{-7}$, equal variance of data sets are not assumed) indicate that the differences in mean values of measured GTX samples are not caused by sampling variation at significance level 0.05 . The null hypothesis ("The true difference in means of peak discharge is equal to zero") was rejected for all comparisons (see Table 6).

In short, all GTX samples significantly delayed the run-off initiation in comparison with the control. Jute J500 proved

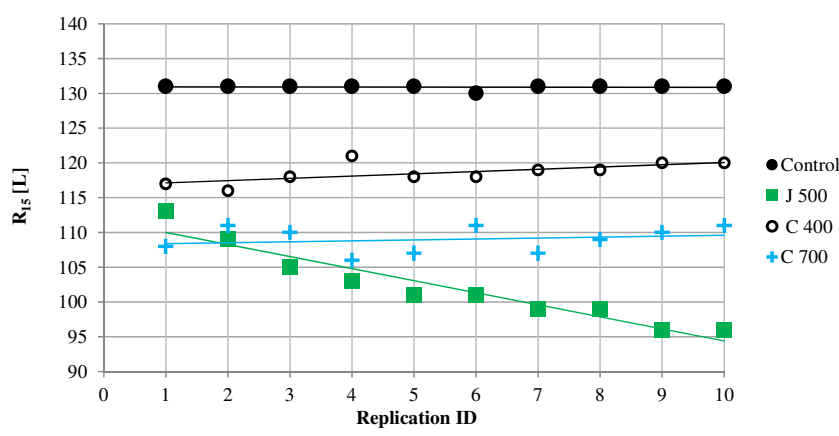

Figure 3. Surface run-off volume at time $=15 \mathrm{~min}, R_{15}(\mathrm{~L})$; linear trend lines included; laboratory conditions.

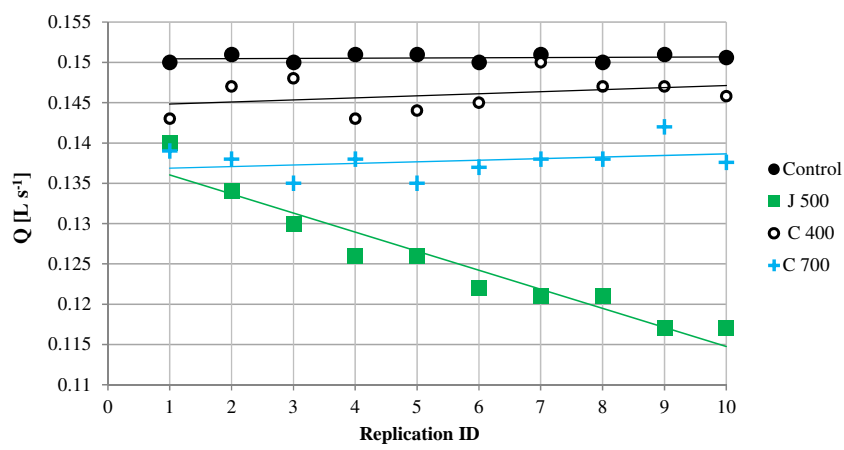

Figure 4. Peak discharge at outlet section, $Q\left(\mathrm{~L} \mathrm{~s}^{-1}\right)$; linear trendlines included; laboratory conditions.

to be significantly more effective than both coir GTXs. No statistically significant difference in time to run-off initiation was found between coir GTXs C400 and C700. Mean values of run-off and discharge are significantly different for all tested GTXs. All GTXs significantly reduced run-off and peak discharge, with jute net J500 being the most effective under laboratory conditions. The results of the rainfall simulation experiments in the laboratory are shown in Figs. 3 and 4.

The mean time to run-off initiation of the simulated rainfall in the field was $295 \mathrm{~s}(792,50$, and $44 \mathrm{~s}$ for the first, second, and third rainfall events) for the control, $120 \mathrm{~s}$ (no runoff observed, 120, $120 \mathrm{~s}$ ) for J500, $268 \mathrm{~s}$ (no runoff observed, 280, $255 \mathrm{~s}$ ) for C400 and $325 \mathrm{~s}$ (no runoff observed, 405, $245 \mathrm{~s}$ ) for C700. For J500, C400, and C700, no run-off was produced during the first rainfall event.

In general, control plots tended to produce the highest runoff volume (L) and discharge ( $\left.\mathrm{L} \mathrm{s}^{-1}\right)$. Concerning the time to run-off initiation, run-off was most quickly produced at the control plot, followed by coir C400, jute J500 and coir C700 in the laboratory. In the field, J500-treated plots produced run-off faster than $\mathrm{C} 700$-treated plots.

The order control - C400 - J500 - C700 matches the impact of GTXs on run-off volume and discharge for the first rainfall event in the laboratory. For the next replications, 
Table 5. Mean run-off ratios $\mathrm{RR}_{15}$ [\%], peak discharge ratios QR [\%] and soil loss SLR [\%] ratios of jute $500 \mathrm{~g} \mathrm{~m}^{-2}(\mathrm{~J} 500), \mathrm{coir}_{400 \mathrm{~g} \mathrm{~m}^{-2}}$ (C400) and coir $700 \mathrm{~g} \mathrm{~m}^{-2}$ (C700) GTXs, compared to control treatments under field and laboratory conditions.

\begin{tabular}{|c|c|c|c|c|c|c|c|c|c|c|c|c|}
\hline & \multicolumn{4}{|c|}{ Mean run-off ratio $\mathrm{RR}_{15}[\%]$} & \multicolumn{4}{|c|}{ Mean peak discharge ratio QR [\%] } & \multicolumn{4}{|c|}{ Mean soil loss ratio SLR [\%] } \\
\hline & control & $\mathrm{J} 500$ & $\mathrm{C} 400$ & $\mathrm{C} 700$ & control & J500 & $\mathrm{C} 400$ & C700 & control & J500 & $\mathrm{C} 400$ & $\mathrm{C} 700$ \\
\hline Lab. & 100 & 78 & 91 & 83 & 100 & 83 & 97 & 91 & 100 & - & - & - \\
\hline Field & 100 & 62 & 79 & 31 & 100 & 74 & 87 & 37 & 100 & 0.6 & 6.2 & 2.1 \\
\hline
\end{tabular}

Table 6. Parameters ( $t$ value, degree of freedom $\mathrm{d} f$ and $p$ value) of the Welch two-sample $t$ test; significance level 0.05 .

\begin{tabular}{lrll|rrr|r|rc}
\hline & \multicolumn{3}{c}{ run-off $t_{i}$} & \multicolumn{3}{c|}{ run-off $R_{15}$} & \multicolumn{3}{c}{ peak discharge $Q$} \\
\cline { 2 - 11 } & \multicolumn{1}{c}{$t$ value } & $\mathrm{d} f$ & $p$ value & $t$ value & $\mathrm{d} f$ & $p$ value & $t$ value & $\mathrm{d} f$ & $p$ value \\
\hline control $\times \mathrm{J} 500$ & -16.53 & 10.42 & $8.18 \times 10^{-9}$ & 16.49 & 9.06 & $4.57 \times 10^{-8}$ & 9.98 & 8.08 & $8.00 \times 10^{-6}$ \\
control $\times \mathrm{C} 400$ & -10.45 & 11.20 & $4.07 \times 10^{-7}$ & 25.28 & 9.79 & $3.02 \times 10^{-10}$ & 5.85 & 8.74 & $2.72 \times 10^{-4}$ \\
control $\times$ C700 & -23.15 & 18.00 & $7.63 \times 10^{-15}$ & 36.22 & 9.51 & $1.65 \times 10^{-11}$ & 26.10 & 10.07 & $1.40 \times 10^{-10}$ \\
$\mathrm{~J} 500 \times \mathrm{C} 700$ & 7.64 & 10.42 & $1.38 \times 10^{-5}$ & -3.70 & 11.09 & 0.0034 & -4.37 & 8.64 & 0.002 \\
$\mathrm{~J} 500 \times \mathrm{C} 400$ & 6.49 & 17.17 & $5.31 \times 10^{-6}$ & -9.11 & 10.34 & $2.93 \times 10^{-6}$ & -7.57 & 9.80 & $2.15 \times 10^{-5}$ \\
$\mathrm{C} 700 \times \mathrm{C} 400$ & -0.44 & 11.20 & 0.672 & -7.57 & 9.80 & $2.15 \times 10^{-5}$ & 9.01 & 13.01 & $5.90 \times 10^{-7}$ \\
\hline
\end{tabular}

an obviously decreasing trend of $R_{15}$ and $Q$ for $\mathrm{J} 500$ was recorded, showing jute GTXs to be the most effective. Other GTXs seemed to provide slightly increasing trends (Figs. 3, 4).

Table 5 shows a comparison of run-off $\left(R_{15}\right)$ and peak discharge $(\mathrm{QR})$ ratios for both laboratory and field conditions. In the laboratory, the greatest decrease in $\mathrm{RR}_{15}$ was recorded by the $\mathrm{J} 500$ jute net $\left(\mathrm{RR}_{15}=78 \%\right)$ in comparison with control $(100 \%)$. The order of effectiveness of each treatment in the laboratory was identical for both run-off volume and peak discharge: (1) J500, (2) C700, and (3) C400.

A different effectiveness ranking was observed in the field. The highest reductions of run-off volume and peak discharge were observed for coir C700 $\left(\mathrm{RR}_{15}=31\right.$, $\left.\mathrm{QR}=37 \%\right)$, followed by jute $\mathrm{J} 500\left(\mathrm{RR}_{15}=62, \mathrm{QR}=74 \%\right)$.

Results of soil loss ratio from the field experiment are also given in Table 5. All GTXs provided a great reduction of soil loss with jute $\mathrm{J} 500$ being the most effective, followed by coir C700 and C400.

\section{Discussion}

\subsection{Time to run-off initiation}

In general, control plots (bare soil/impermeable plastic film without GTXs) have a significantly faster response to rainfall than GTX-treated plots (also reported by Cerdà et al., 2009). The performance of GTXs seems to be highly influenced by the infiltration rate, as the surface run-off was initiated after less than $30 \mathrm{~s}$ on impermeable subgrade (laboratory experiment) and after 2-6 min on soil (field experiment). The very short time to run-off initiation means that any thunder- storm will contribute to run-off and soil loss on sloping bare soil (Cerdà et al., 2009). The high bulk density of the soil $\left(1.40 \mathrm{~g} \mathrm{~cm}^{-3}\right.$, frequently a feature of slopes created during civil engineering projects) can explain the fast run-off initiation, and the large run-off volumes and available sediment are due to raindrop impact on bare soils (Cerdà and Jurgensen, 2008).

The results of laboratory-based rainfall simulations indicated that GTXs significantly delayed the time to run-off initiation. Similar results were obtained by Shao et al. (2014) and Sutherland and Ziegler (2007). According to mean values, C700 performed better than J500. When studying the results of individual replications, J500 reached the peak discharge earlier than $\mathrm{C} 700$, but the discharge values remained lower. Time to run-off initiation was longer for C700, but higher peak discharge values were observed. The better performance of jute J500 compared to both coir GTXs was probably caused by lower water-absorbing capacity and lower flexibility of coir GTXs, due to which the GTXs did not lay directly on the subgrade, allowing water to flow over a smoother surface under the GTXs. The same observation was previously reported by Rickson (2006). In the literature, significant differences between GTX-covered and control (bare soil) plots were confirmed by Sutherland and Ziegler (2007). In other studies, such differences were not proven (Rickson, 2000). A possible explanation could be the different infiltration capacity of used soil subgrade. Rickson (2000) used more permeable sandy loam, while Sutherland and Ziegler (2007) used clay (see Table 1); therefore it seems that the smoother and less permeable the subgrade, the higher the delay of the GTX effect, as the low infiltration ca- 
pacity of the subgrade provides a higher volume of surface run-off.

\subsection{Run-off volume reduction}

The results of the laboratory simulations showed a significant decrease in run-off volume [L] from the GTX-treated plots. Similar results were reached by Khan and Binoy (2012), Shao et al. (2014) and Sutherland and Ziegler (2007; see Table 1). On the contrary, some studies (both field and laboratory) concluded that GTXs increase the run-off volume (Álvarez Mozos et al., 2014; Giménez-Morera et al., 2010; Kertézs et al., 2007). The increase might be caused by a dense cover of GTXs (Mitchel et al., 2003) or high slope gradient, where water can flow through the GTX fibres without infiltration into the soil (Álvarez-Mozos et al., 2014). In this study, the run-off control effect of GTXs was supported by the infiltration process, leading to a higher run-off reduction in the field in comparison to the laboratory, despite a higher slope gradient $\left(27^{\circ}\right)$.

The authors presumed that due to the infiltration process, soil would support the erosion control effect of GTXs, providing less water for overland flow (Beven, 2011). Assuming that soil affects all GTXs equally in the field, the laboratory records of surface run-off volume (L) and peak discharge $\left(\mathrm{L} \mathrm{s}^{-1}\right)$ reduction should proportionally match data from field experiments. However, the GTX effectiveness ranking in the laboratory significantly differed from the field data. In the laboratory the run-off ratios of 78,83 , and $91 \%$ were recorded for jute $\mathrm{J} 500$, coir $\mathrm{C} 700$ and coir C400 respectively. In the field, the run-off ratios were the following: 62, 31, and $79 \%$ for the same order of GTXs (see Table 5). Coir GTX C700 performed with significantly higher run-off reduction than jute $\mathrm{J} 500$ in the field. The same results were reported by Álvares-Mozos et al. (2014) from a $60^{\circ}$ slope, while on $45^{\circ}$ slope jute performed better than coir. If more replications were carried out in the field, a different trend possibly might be found, because a decreasing trend of run-off volume is clear for jute J500 under laboratory "no-soil" conditions, while coir C700 shows an increasing trend (see Fig. 3). Similar behaviour was observed in the field, where the run-off ratio of 66 and $59 \%$ (first and second replication) was observed for J500, and 24 and $38 \%$ was observed for C700. More replications in the field would indicate whether the decreasing trend for jute and increasing trend for coir will continue.

Higher run-off reduction by $\mathrm{C} 700$ might also be explained by its slightly higher loop size in comparison with $\mathrm{J} 500$ (see Table 2). In theory, C700 might provide more space for rainwater to fall directly to the soil surface and then infiltrate, which would lead to lower surface run-off volume. However, on the jute-treated plot the rainwater was initially absorbed by the fibres and then brought down through them due to gravity.

\subsection{Soil loss reduction}

According to the laboratory test, jute J500 seemed to have the highest impact on peak discharge and run-off velocity. Therefore, lower shear stress might be assumed for jute J500 (Thompson, 2001) than for coir GTXs, leading to lower erosion rate in the field. This was confirmed both in the field experiment of this study and in the work of Rickson (2000, 2006). All GTXs significantly reduced soil loss (see Table 5). Despite much higher run-off volume from the jute-treated plot, SLR equalled to $0.6 \%$ for jute $\mathrm{J} 500$, followed by coir C700 with SLR $=2.1 \%$. The performance of jute and coir C700 may be considered to be comparable, as the small difference might have been caused by a soil loss measurement error.

Álvarez-Mozos et al. (2014) reported similar behaviour from jute and coir GTXs. In their study, jute performed better for run-off reduction but resulted in higher soil loss than coir on a $45^{\circ}$ slope. On a $60^{\circ}$ slope the situation was reversed: jute showed more run-off reduction but better erosion control than coir. The authors explain this with the theory that on gentle or moderate slopes, biological GTXs might absorb rainwater and slow run-off generation, whereas on steep slopes water can slip through the GTX fibres and create superficial flow paths without infiltrating into the soil. This factor seems to be more relevant for jute than coir due to its higher water absorbing capacity (Gosh, 2014). In this study, the run-off control effect of GTXs varied under different slope gradients even when lower values (9 and $27^{\circ}$ ) were used. It is interesting that differences in performance were recorded for slope ranges which do not overlap ( $9^{\circ} \mathrm{vs}$. $27^{\circ}$ and $45^{\circ}$ vs. $60^{\circ}$ ). A threshold value of slope gradient, at which GTX behaviour changes, needs to be established. Potentially, if the field and laboratory experiments were both carried out on a slope gradient either below or above this threshold, the match between data sets would be reached.

The rigidity of GTX fibres may play an important role too, as the smoother structure of jute GTX fibres probably provides better conditions for the flow of water compared to the tougher coir fibres.

Furthermore, the contact between GTXs and soil plays a very important role (Midha and Suresh Kumar, 2013). It seems to decrease as the slope gradient and GTX material rigidity increases (Chen et al., 2011; Midha and Suresh Kumar, 2013). This may apply to this study - jute probably absorbed more rainwater into its fibres and due to gravity this water was brought down through the fibres, causing almost no erosion. Despite being provided by the same supplier, coir C700 was visually observed to have slightly higher cover in the field (manufacturing variability). This might have led to higher retention of rainwater, but because of lower contact with the soil due to its rigidity, the erosion rate of plots with coir was higher than for those with jute. Another explanation might be that due to the structure of fibres, water flows more slowly through coir than through jute. Additionally, coir fi- 
bres create higher obstacles for overland flow due to their larger diameter and also the clogging of spaces among fibres. Therefore, at the coir C700 plot the water run-off was lower but the sediment content was higher. Further investigation of the interaction between eroded soil particles and GTX fibres during rainfall events would be valuable for testing this theory. According to this experiment, it seems that slope gradient is not the only factor determining GTX performance. Soil characteristics and GTX-soil interface need to be considered along with the slope gradient.

The field experiment was carried out on a steeper slope $\left(27^{\circ}\right)$ than the laboratory experiment $\left(9^{\circ}\right)$. Authors proceeded to compare these two data sets because, according to some studies, GTX effectiveness increases with the slope gradient (Morgan, 2005). This fact was partly confirmed by ÁlvarezMozos et al. (2014), who examined the impact of GTXs on run-off volume and soil loss on 45 and $60^{\circ}$ slopes. On the $45^{\circ}$ slope the soil loss was reduced by 69 and $90 \%$ by jute and coir respectively. On the $60^{\circ}$ slope, the reduction was $60 \%$ for jute and $56 \%$ for coir. Again, different behaviours (performance ranking) were recorded with changing slope, which makes it necessary to find slope gradient threshold values beyond which the performance of GTXs changes. In this study it is not possible to determine whether the soil erosion control performance increased in the field, as "no-soil" conditions were used in the laboratory. Furthermore, without any other field records of lower slope gradients and same soil conditions for comparison, it would be highly complicated to separate erosion control effects of GTXs from the impact of soil infiltration on soil loss in the field. Also, lower rainfall intensity applied to the field for operational reasons might slightly modify the results. But for a pilot research on whether the performance ranking of GTXs is the same in the field as in the laboratory, this deviation might be acceptable. For further research more consistent conditions would definitely be required, but the data presented here shed more light on the behaviour of GTXs under different site conditions.

\section{Conclusions}

Jute and coir GTXs tested in this study can significantly delay the initiation of surface run-off under the simulated rainfall, when compared to control plots (bare soil in the field, impermeable plastic film in the laboratory) without GTXs. Control plots tended to produce significantly higher run-off volume [L], discharge $\left[\mathrm{L} \mathrm{s}^{-1}\right]$, and soil loss [g] than GTXtreated plots.

In the laboratory, jute J500 showed an increasing trend of run-off control, unlike coir GTXs, the performance of which gradually decreased. Further investigation is needed to prove whether this behaviour also appears in the field.

Regardless of the conditions (slope, laboratory vs. field), coir C400 seemed to be less effective than jute J500 and coir C700. The run-off control performance of jute J500 and coir C700 significantly differed between the "no-soil" laboratory and field conditions, but all GTXs provided a great reduction of soil loss with jute $\mathrm{J} 500$ being the most effective, followed by coir C700 and C400. The theory that soil would influence the performance of all GTXs equally (same effectiveness ranking in the laboratory as in the field) was not confirmed, which makes it necessary to find slope gradient threshold values beyond which the performance of GTX changes. The influence of the slope gradient and GTX-soil contact on run-off and soil loss reduction still needs to be investigated in detail. Another experimental testing of GTX effectiveness using different slope gradient and soil subgrade is suggested by authors.

Author contributions. Jana Kalibová designed the experiments and carried them out together with Jan Petrů. Lukáš Jačka performed laboratory and statistical analyses. Jana Kalibová prepared the manuscript with contributions from all co-authors.

Acknowledgements. This experiment was supported by the Internal Grant Agency of Czech University of Life Sciences Prague, grant IGA 20144225. The authors are grateful to their colleagues from the Faculty of Environmental Sciences, who helped with fieldwork.

Edited by: A. Jordán

\section{References}

Álvarez-Mozos, J., Abad, E., Giménez, R., Campo, M. A., Goñi, M., Arive, M., Casalí, J., Díez, J., and Diego, I.: Evaluation of erosion control geotextiles on steep slopes, Part 1: Effects of runoff and soil loss, Catena, 118, 168-178, doi:10.1016/j.catena.2013.05.018, 2014.

ASTM: Standard test methods for moisture, ash, and organic matter of peat and other organic soils, Method D 2974-00, American Society for Testing and Materials, West Conshohocken, Pennsylvania, 2000.

Berendse, F., van Ruijven, J., Jongejans, E., and Keesstra, S.: Loss of plant species diversity reduces soil erosion resistance, Ecosystems, 18, 881-888, doi:10.1007/s10021-015-9869-6, 2015.

Beven, K. J.: Rainfall-runoff modelling: the primer, John Wiley \& Sons, 449 pp., ISBN:978-0-470-71459-1, 2011.

Bhattacharyya, R., Smets, T., Fullen, M. A., Poesen, J., and Booth, C. A.: Effectiveness of geotextiles in reducing runoff and soil loss: A synthesis, Catena, 81, 184-195, doi:10.1016/j.catena.2010.03.003, 2010.

Brevik, E. C., Cerdà, A., Mataix-Solera, J., Pereg, L., Quinton, J. N., Six, J., and Van Oost, K.: The interdisciplinary nature of SOIL, SOIL, 1, 117-129, doi:10.5194/soil-1-117-2015, 2015.

Cantón, Y., Solé-Benet, A., de Vente, J., Boix-Fayos, C., CalvoCases, A., Asensio, C., and Puigdefábregas, J.: A review of runoff generation and soil erosion across scales in semiarid south-eastern Spain, J. Arid Environ., 75, 1254-1261, doi:10.1016/j.jaridenv.2011.03.004, 2011. 
Cerdà, A.: Effect of climate on surface flow along a climatological gradient in Israel: A field rainfall simulation approach, J. Arid Environ., 38, 145-159, doi:10.1006/jare.1997.0342, 1998.

Cerdà, A.: Soil water erosion on road embankments in eastern Spain, Sci. Total Environ., 378, 151-155, doi:10.1016/j.scitotenv.2007.01.041, 2007.

Cerdà, A. and Jurgensen, M.: The influence of ants on soil and water losses from an orange orchard in eastern Spain, J. Appl. Entomol., 132 , 306-314, doi:10.1111/j.1439-0418.2008.01267.x, 2008.

Cerdà, A., Giménez-Morera, A., and Bodí, M. B.: Soil and water losses from new citrus orchards growing on sloped soils in the western Mediterranean basin, Earth Surf. Proc. Land., 34, 18221830, doi:10.1002/esp.1889, 2009.

Cerdà, A., Lavee, H., Romero-Díaz, A., Hooke, J., and Montanarella, L.: Soil erosion and degradation in mediterranean type ecosystems, Land Degrad. Dev., 21, 71-74, doi:10.1002/ldr.968, 2010.

Chen, S. C., Chang, K. T., Wang, S. H., and Lin, J. Y.: The efficiency of artificial materials used for erosion control on steep slopes, Earth Sci. Environ., 62, 197-206, doi:10.1007/s12665010-0514-6, 2011.

Davies, K., Fullen, M. A., and Booth, C. A.: A pilot project on the potential contribution of palm-mat geotextiles to soil conservation, Earth Surf. Proc. Land., 31, 561-569, doi:10.1002/esp.1349, 2006.

Decock, C., Lee, J., Necpalova, M., Pereira, E. I. P., Tendall, D. M., and Six, J.: Mitigating $\mathrm{N}_{2} \mathrm{O}$ emissions from soil: from patching leaks to transformative action, SOIL, 1, 687-694, doi:10.5194/soil-1-687-2015, 2015.

Erkossa, T., Wudneh, A., Desalegn, B., and Taye, G.: Linking soil erosion to on-site financial cost: lessons from watersheds in the Blue Nile basin, Solid Earth, 6, 765-774, doi:10.5194/se-6-7652015, 2015.

Fifield, J. S.: How effective are erosion control products in assisting with dryland grass establishment with no irrigation?, Proceedings of the XXIII th IECA Annual Conference "The environment is our future", Reno, Nevada, February 1992, 321-334, 1992.

Fullen, M. A., Booth, C. A., Sarsby, R. W., Davies, K., Kugan, R., Bhattacharyya, R., Subedi, M., Poesen, J., Smets, T., Kertész, Á., Tóth, A., Szalai, Z., Jakab, G., Kozma, K., Jankauskas, B., Jankauskiene, G., Bühmann, C., Paterson, G., Mulibana, E., Nell, J. P., van der Merwe, G. M. E., Guerra, A. J..T., Mendonça, J. K. S., Guerra, T. T., Sathler, R., Bezerra, J. F. R., Peres, S. M., Yi, Z., Yongmei, L., Li, T., Panomtarachichigul, M., Peukrai, S., Thu, D. C., Cuong, T. H., Toan, T. T., Jonsyn-Ellis, F., Jallow, S., Cole, A., Mulholland, B., Dearlove, M., and Corkill, C.: Contributions of biogeotextiles to sustainable development and soil conservation in developing countries: the BORASSUS Project, in: Ecosyst. Sustain. Dev. WIT Press, Southampton (UK), 123$141,2007$.

Giménez-Morera, A., Ruiz Sinoga, J. D., and Cerdà, A.: The impact of cotton geotextiles on soil and water losses from mediterranean rainfed agricultural land, Land Degrad. Dev., 21, 210217, doi:10.1002/ldr.971, 2010.

Gosh, S. K.: A Review on Jute Geotextile and its Geo-Technical Applications with respect to Environmental Concern. International Journal of Innovative Research in Science \& Engineering, avail- able at: http://ijirse.in/docs/Dec13/IJIRSE1607.pdf, (last access: 12 January 2015), 2014.

Harmon, R. S. and Doe, W. W. (Eds.): Landscape Erosion and Evolution Modeling, Kluwer, New York, 540 pp., ISBN:0-30646718-6, 2001.

Hu, Y.-L., Niu, Z.-X., Zeng, D.-H., and Wang, C.-Y.: Soil Amendment Improves Tree Growth and Soil Carbon and Nitrogen Pools in Mongolian Pine Plantations on Post-Mining Land in Northeast China, Land Degrad. Dev., 26, 807-812, doi:10.1002/ldr.2386, 2015.

Hueso-González, P., Martínez-Murillo, J. F., and Ruiz-Sinoga, J. D.: The impact of organic amendments on forest soil properties under Mediterranean climatic conditions, Land Degrad. Dev., 25, 604-612, doi:10.1002/ldr.2150, 2014.

Ingold, T. S. and Thomson, J. C.: Results of current research of synthetic and natural fiber erosion control systems. Erosion Control: Proceedings of Conference XVII, International Erosion Control Association, 17-28 February, Dallas, Texas, 65-73, 1986.

Iserloh, T., Ries, B. J., Cerdà, A., Echeverría, M. T., Fister, W., Geißler, C., Kuhn, N. J., León, F. J., Peters, P., Schindewolf, M., Schmidt, J., Scholten, T., and Seeger, M.: Comparative measurements with seven rainfall s simulators on uniform bare fallow land, Z. Geomorphol., 57, 1-10, doi:10.1127/0372-8854/2012/S00085, 2013a.

Iserloh, T., Ries, J. B., Arnáez, J., Boix-Fayos, C., Butzen, V., Cerdà, A., Echeverría, M. T., Fernández-Gálvez, J., Fister, W., Geißler, C., Gómez, J.A., Gómez-Macpherson, H., Kuhn, N. J., Lázaro, R., León, F. J., Martínez-Mena, M., Martínez-Murillo, J. F., Marzen, M., Mingorance, M. D., Ortigosa, L., Peters, P., Regüés, D., Ruiz-Sinoga, J. D., Scholten, T., Seeger, M., SoléBenet, A., Wengel, R., and Wirtz, S.: European small portable rainfall simulators: A comparison of rainfall characteristics, Catena, 110, 100-112, doi:10.1016/j.catena.2013.05.013, 2013b.

Jakab, G., Szalai, Z., Kertész, Á., Tóth, A., Madarász, B., and Szabó, S.: Biological geotextiles against soil degradation under subhumid climate - a case study, Carpath. J. Earth Env., 7, 125-134, 2012.

Jordán, A., Zavala, L. M., and Muñoz-Rojas, M.: Mulching, effects on soil physicial properties, in: Encyclopedia of Agrophysics, edited by: Glinski, J., Horabik, J., and Lipiec, J., Springer, Dordrecht, 492-496, 2011.

Keesstra, S., Pereira, P., Novara, A., Brevik, E.C., AzorinMolina, C., Parras-Alcántara, L., Jordán, A., and Cerdà, A.: Effects of soil management techniques on soil water erosion in apricot orchards, Sci. Total Environ., 357-366, doi:10.1016/j.scitotenv.2016.01.182, 2016.

Keesstra, S. D., Geissen, V., van Schaik, L., Mosse., K., and Piiranen, S.: Soil as a filter for groundwater quality, Current Opinions in Environmental Sustainability, 4, 507-516, doi:10.1016/j.cosust.2012.10.007, 2012.

Keesstra, S. D., Maroulis, J., Argaman, E., Voogt, A., and Wittenberg, L.: Effects of controlled fire on hydrology and erosion under simulated rainfall, Cuader. Invest. Geográf., 40, 269-293, doi:10.18172/cig.2532, 2014.

Kertész, A., Toth, A., Szalai, Z., Jakab, G., Kozma, K., Booth, C. A., Fullen, M. A., and Davies K.: Geotextile as a tool against soil erosion in vineyards and orchards, in: Sustainable Development and Planning III, edited by: Kungolas, A., Brebbia, C. A., 
and Beriatos, E., Vol. 2, WIT Press, Southampton, UK, 611-619, 2007.

Khan, A. J. and Binoy, T. H.: Top Soil Erosion Control Using Geojute,. Proceedings of International Conference on Advances in Civil Engineering, Delhi, India, 28-29 December, 146-150, 2012.

Kutílek, M. and Nielsen, D. R.: Soil Hydrology, Catena Verlag, Cremlingen, Destedt, Germany, 370 pp., ISBN 3-923381-26-3, 1994.

Langford, R. L. and Coleman, M. J.: Biodegradable erosion control blankets prove effective on Iowa wildlife refuge, Proceedings of XXVII th International Erosion Control Association Conference, Seattle, USA, March 1996, 13-20, 1996.

Lekha, K. R.: Field instrumentation and monitoring of soil erosion in coir geotextile stabilized slopes - A case study, Geotext. Geomembr., 22, 399-413, doi:10.1016/j.geotexmem.2003.12.003, 2004.

Lieskovský, J. and Kenderessy, P.: Modelling the effect of vegetation cover and different tillage practices on soil erosion in vineyards: A case study in vráble (Slovakia) using WATEM/SEDEM, Land Degrad. Dev., 25, 288-296, doi:10.1002/ldr.2162, 2014.

Luo, H., Zhao, T., Dong, M., Peng, X., Guo, Y., Wang, Z., and Liang, C.: Field studies on the effect of three geotextiles on runoff and erosion of road slope in Beijing, China, Catena, 109, 150-156, doi:10.1016/j.catena.2013.04.004, 2013.

Martínez-Murillo, J. F., Nadal-Romero, E., Regüés, D., Cerdà, A., and Poesen, J.: Soil erosion and hydrology of the western Mediterranean badlands throughout rainfall simulation experiments: A review, Catena, 106, 101-112, doi:10.1016/j.catena.2012.06.001, 2013.

Midha, V. K. and Suresh Kumar, S.: Influence of woven structure on coir rolled erosion-control products, Geosynth. Internation., 20, 396-407, doi:10.1680/gein.13.00027, 2013.

Mitchell, D. J., Barton, A. P, Fullen, M. A., Hocking, T. J., Zhi, W. B., and Yi, Z.: Field studies of the effects of jute geotextiles on runoff and erosion in Shropshire, UK, Soil Use Managem., 19, 182-184, doi:10.1111/j.1475-2743.2003.tb00301.x, 2003.

Moreno-Ramón, H., Quizembe, S. J., and Ibáñez-Asensio, S.: Coffee husk mulch on soil erosion and runoff: experiences under rainfall simulation experiment, Solid Earth, 5, 851-862, doi:10.5194/se-5-851-2014, 2014.

Morgan, R. C. P.: Soil Erosion and Conservation (third edition), Blackwell Publishing, Oxford, UK, 304 pp., 2005.

Morgan, R. P. C. and Rickson, R. J. (Eds.): Slope Stabilization and Erosion Control: A Bioengineering Approach Morgan, E \& FN SPON, Cranfield, UK, 274 pp., 1995.

Nelson, D. W. and Sommers L. E.: Total carbon, organic carbon, and organic matter, in: Methods of Soil Analysis, edited by: Page A. L., Miller. R. H., and Keeney, D. R., Part 2, Second Edition, Agronomy, 9, 539-580, Am. Soc. Agron., Inc. Madison, Winsconsin, 1982.

Ogbobe, O., Essien, K. S., and Adebayo, A.: A study of biodegradable geotextiles used for erosion control. Geosynth, Internation, 5, 545-553, doi:10.1680/gein.5.0131, 1998.

Ola, A., Dodd, I. C., and Quinton, J. N.: Can we manipulate root system architecture to control soil erosion?, SOIL, 1, 603-612, doi:10.5194/soil-1-603-2015, 2015.

Pereira, P., Gimeìnez-Morera, A., Novara, A., Keesstra, S., Jordán, A., Masto, R. E., Brevik, E., Azorin-Molina, C., and Cerdà, A.:
The impact of road and railway embankments on runoff and soil erosion in eastern Spain, Hydrol. Earth Syst. Sci. Discuss., 12, 12947-12985, doi:10.5194/hessd-12-12947-2015, 2015.

Prosdocimi, M., Jordán, A., Tarolli, P., Keesstra, S., Novara, A., and Cerdà, A.: The immediate effectiveness of barley straw mulch in reducing soil erodibility and surface runoff generation in Mediterranean vineyards. Sci. Total Environ., 547, 323-330, doi:10.1016/j.scitotenv.2015.12.076, 2016.

Rickson, R. J.: The use of geotextiles in soil erosion control: comparison of performance on two soils, in: Proceedings of Land Conservation for Future Generations, edited by: Rimwanich, S. V., International Soil Conservation, Bangkok, Thailand, January 1998, 961-970, 1988.

Rickson, R. J.: The use of geotextiles for soil erosion control, Ph. D. thesis, Cranfield University, Cranfield, UK, 295 pp., 2000.

Rickson, R. J.: Management of sediment production and prevention in river catchments: A matter of scale?, in: Soil Erosion and Sediment Redistribution in River Catchments: Measurement, edited by: Owens, P. N. and Collins, A. J., Modelling and Management, CAB International, Wallingford, UK, 228-238, 2005.

Rickson, R. J.: Controlling sediment at source: an evaluation of erosion control geotextiles, Earth Surf. Proc. Land., 31, 550-560, doi:10.1002/esp.1368, 2006.

Rodrigo Comino, J., Brings, C., Lassu, T., Iserloh, T., Senciales, J. M., Martínez Murillo, J. F., Ruiz Sinoga, J. D., Seeger, M., and Ries, J. B.: Rainfall and human activity impacts on soil losses and rill erosion in vineyards (Ruwer Valley, Germany), Solid Earth, 6, 823-837, doi:10.5194/se-6-823-2015, 2015.

Rodrigo Comino, J., Iserloh, T., Morvan, X., Malam Issa, O., Naisse, C., Keesstra, S. D., Cerdà, A., Prosdocimi, M., Arnáez, J., Lasanta, T., Ramos, M. C., Marqués, M. J., Ruiz Colmenero, M., Bienes, R., Ruiz Sinoga, J. D., Seeger, M., and Ries, J. B.: Soil Erosion Processes in European Vineyards: A Qualitative Comparison of Rainfall Simulation Measurements in Germany, Spain and France, Hydrology, 3, doi:10.3390/hydrology3010006, 2016.

Sadeghi, S. H. R., Gholami, L., Sharifi, E., Khaledi Darvishan, A., and Homaee, M.: Scale effect on runoff and soil loss control using rice straw mulch under laboratory conditions, Solid Earth, 6, 1-8, doi:10.5194/se-6-1-2015, 2015.

Schumacher, B. A.: Methods for the determination of the total organic carbon (TOC) in soils and sediments, US Environmental Protection Agency, 1-23, Washington DC, 2002.

Seutloali, K. E. and Beckedahl, H. R.: Understanding the factors influencing rill erosion on roadcuts in the south eastern region of South Africa, Solid Earth, 6, 633-641, doi:10.5194/se-6-6332015, 2015.

Shao, Q., Gu, W., Dai, Q., Makoto, S., and Liu, Y.: Effectiveness of geotextile mulches for slope restoration in semi-arid northern China, Catena, 116, 1-9, doi:10.1016/j.catena.2013.12.006, 2014.

SIST-TS CEN ISO/TS 17892-4:2004: Geotechnical Investigation and Testing - Laboratory Testing of Soil - Part 4: Determination of Particle Size Distribution (ISO/TS 17892-4:2004), Inštitut za standardizacijo, Slovenija, 2004.

Smets, T., Poesen, J., Bhattacharyya, R., Fullen, M. A., Subedi, M., Booth, C. A., Kertesz, A., Szalai, Z., Toth, A., Jankauskiene, G., Guerra, A. J. T., Bezerra, J. F. R., Yi, Z., Panomtaranichagul, M., Buhmann, C., and Paterson, G.: Evaluation of biological geotex- 
tiles for reducing runoff and soil loss under various environmental conditions using laboratory and field plot data, Land Degrad. Dev, 22, 480-494, doi:10.1002/ldr.1095, 2011.

Smith, P., Cotrufo, M. F., Rumpel, C., Paustian, K., Kuikman, P. J., Elliott, J. A., McDowell, R., Griffiths, R. I., Asakawa, S., Bustamante, M., House, J. I., Sobocká, J., Harper, R., Pan, G., West, P. C., Gerber, J. S., Clark, J. M., Adhya, T., Scholes, R. J., and Scholes, M. C.: Biogeochemical cycles and biodiversity as key drivers of ecosystem services provided by soils, SOIL, 1, 665685, doi:10.5194/soil-1-665-2015, 2015.

Stanchi, S., Falsone, G., and Bonifacio, E.: Soil aggregation, erodibility, and erosion rates in mountain soils (NW Alps, Italy), Solid Earth, 6, 403-414, doi:10.5194/se-6-403-2015, 2015.

Sutherland, R. A. and Ziegler, A. D.: Hillslope runoff and erosion as affected by rolled erosion control systems: a field study, Hydrol. Process., 20, 2839-2855, doi:10.1002/hyp.6078, 2006.

Sutherland, R. A. and Ziegler, A. D.: Effectiveness of coirbased rolled erosion control systems in reducing sediment transport from hillslopes, Appl. Geogr., 27, 150-164, doi:10.1016/j.apgeog.2007.07.011, 2007.
Thompson, A. M.: Shear stress partitioning for vegetation and erosion control blankets, Ph. D. thesis, Department of Biosystems and Agricultural Engineering, University of Minnesota, St. Paul, Minnesota (UMI Number: 3032015), 2001.

Tolasz, R.: Atlas podnebí Česka: Climate Atlas of Czechia, 1st edition, Czech Hydrometeorological Institute, Prague, Czech Republic, 255 pp., 2007.

Toy, T. J. and Hadley, R. F.: Geomorphology and reclamation of disturbed lands, Earth Surf. Proc. Land., 14, 754-755, 1987.

Weggel, J. R. and Rustom, R.: Soil Erosion by Rainfall and Runoff - State of the Art, Goetext. Geomembr., 11, 551-572, doi:10.1016/0266-1144(92)90032-6, 1992.

Yazdanpanah, N., Mahmoodabadi, M., and Cerdà, A.: The impact of organic amendments on soil hydrology, structure and microbial respiration in semiarid lands, Geoderma, 266, 58-65, doi:10.1016/j.geoderma.2015.11.032, 2016.

Yuan, Y., Jiang, Y., Taguas, E. V., Mbonimpa, E. G., and Hu, W.: Sediment loss and its cause in Puerto Rico watersheds, SOIL, 1, 595-602, doi:10.5194/soil-1-595-2015, 2015. 